\title{
Computermediets differentieringspotentiale i sproglig læring belyst ud fra en procesorienteret synsvinkel
}

\begin{abstract}
The main point of this article is to demonstrate that the existence of the computermedium within L $2^{1}$ learning and acquisition is justified by its potential of differentiation. In order to make the optimum use of this potential, it is necessary to design syllabi based on L2 research and theories of language learning acquisition. Taking as a starting point the learner's interlanguage development, I am introducing a model of L2 learning and acquisition, a model based on input as well as on output. The strong point in having this model is that you can use it for computer-assisted language learning, and in this way you can contribute to the implementation of differentiated syllabi that take into account the psycholinguistic processes that characterize interlanguage development.
\end{abstract}

\section{Indledning}

\subsection{Relationen imellem IT og sproglig læring}

„Media are mere vehicles that deliver instruction but do not influence student achievement any more than the truck that delivers our groceries causes changes in our nutrition“ (Clark 1983:91).

„As pointed out by Garrett (1991), ,the use of the computer does not constitute a method“. Rather, it is a ,medium in which a variety of methods, approaches, and pedagogical philosophies may be implemented" (ibid: 75). The effectiveness of CALL ${ }^{2}$ cannot reside in the medium itself but only in how it is put to use" (Warschauer 1996:6).

1 L2: second language.

2 CALL: computer-assisted language learning.

* Lone Ambjørn

Handelshøjskolen i Arhus

Fuglesangs Allé 4

DK-8210 Arhus $V$

lam@asb.dk 
Med disse citater belyses den overordnede synsvinkel, jeg i denne artikel lægger til grund for relationen imellem IT og sproglig læring 3 : computermediets integration i fremmedsprogsundervisningen har kun et læringspotentiale, hvis der sker en tilpasning til en teoretisk og opdateret viden om de processer, der ligger bag sproglig læring. En hensigtsmæssig forløbstilrettelæggelse bliver ikke pr. definition mere hensigtsmæssig via IT-integration, lige så lidt som en uhensigtsmæssig tilrettelæggelse nødvendigvis forbedres, fordi diverse sproglige aktiviteter udføres ad elektronisk vej. Rent faktisk vil man kunne finde eksempler på, at IT kan forringe læringspotentialet i et forløb, enten fordi man ikke tilstrækkeligt kritisk har evalueret det elektroniske materiales anvendelighed, eller fordi computermediet p.t. er uegnet til gennemførelse af givne aktiviteter.

Når jeg finder anledning til at berøre tilpasningsretningen imellem computer og sproglig læring, skal det ses på baggrund af, at en forholdsmæssig stor part af det computerbaserede undervisningsmateriale, der udvikles, lader en del tilbage at ønske, hvad angår dets læringsmæssige potentiale. Siden 1980'erne, hvor computeren for alvor gjorde sit indtog i undervisningssammenhæng, er der ikke uden grund fremsat kritik af de elektroniske sprogprogrammer, der løbende er dukket op på markedet. Man kunne måske forestille sig, at dette på daværende tidspunkt var tegn på dels begyndervanskeligheder med at håndtere mediet, dels producenternes iver efter at udnytte den stærkt stigende interesse for computerbaseret materiale på bekostning af kvaliteten. Men desværre har billedet ikke ændret sig nævneværdigt siden. Selv om der er glædelige undtagelser fra reglen, forholder det sig fortsat sådan, at for lidt elektronisk materiale udvikles på baggrund af et eksplicit kendskab til den nyere forskning inden for fremmedsproglige læringsprocesser. Programudviklingen bærer i for høj grad præg af en forveksling imellem computeren som mål og middel samt manglende inddragelse af sprogpædagogisk og læringsteoretisk ekspertviden.

Af denne årsag er man som underviser nødt til på et forskningsbaseret og kritisk grundlag at vurdere, hvordan og i hvilket omfang forskellige sprogteknologiske ressourcer optimalt kan understøtte et undervisningsforløb med fokus på selve sproglæringsprocessen.

3 Jeg anvender termen laering som en samlet benævnelse for indlcering og tilegnelse. 


\subsection{To anvendelser af computerteknologien}

Det skal pointeres, at jeg skelner imellem

1) anvendelse af computerteknologien som et elektronisk redskab med en tidsbesparende og effektiviserende værdi i en (sam)arbejdsproces for undervisere og studerende. Eksempler herpå er hjemmesiden som kilde til informationsformidling imellem underviser og studerende, kommunikationssystemer (som fx CampusNet), præsentationsværktøjer osv. Fælles for disse redskaber er, at de ikke direkte påvirker den sproglige læringsproces.

2) anvendelse af teknologien som elektronisk læringsressource, der faciliterer selve den intersproglige udvikling og har et sprogligt færdighedsfokuserende sigte. Eksempler herpå er materialer til oparbejdelse af fx morfologisk, syntaktisk og leksikalsk kompetence, inddragelse af computermedieret kommunikation, hvorved forstås fremmedsproglig kommunikation via mail, chat, diskussionsfora mv.

Det er computerteknologien som elektronisk læringsressource, der skal i fokus her.

\subsection{Procesorienteret undervisningsdifferentiering}

I det heterogene læringsrum tilpasses undervisningens niveau, indhold og form ofte en standardiseret forløbsmodel, der formodes at være i overensstemmelse med den "typiske“ studerendes færdigheder, behov og interesser. Sådanne one-size-fits-all modeller møder ikke den enkelte studerende dér, hvor han rent faktisk befinder sig i sin intersproglige udvikling, men forudsætter, at de ,atypiske“ studerende tilpasser sig normen. Hermed mener jeg ikke, at der er noget forkert $i$ at have fagbeskrivelser og læseplaner indeholdende bestemmelser om, hvad der skal undervises $\mathrm{i}$, når blot disse beskrivelser kan gøres forenelige med en differentieret undervisning, som fokuserer på, hvordan et givet forløb kan tilpasses den individuelle sprogindlærer:

„Choose any standard. Differentiation suggests that you can challenge all learners by providing materials and tasks on the standard at varied levels of difficulty, with varying degrees of scaffolding, through multiple instructional groups, and with time variations. Further, differentiation suggests that teachers can craft lessons in ways that tap into multiple student interests to promote heightened learner interest in the standard. Teachers can encourage student success by varying ways in which 
students work: alone or collaboratively, in auditory or visual modes, or through practical or creative means" (Tomlinson 2000:4).

Når der argumenteres for at differentiere sprogundervisningen med henblik på at højne læringspotentialet hos den enkelte sprogindlærer ${ }^{4}$, er der generelt en vis tilbøjelighed til kun at fokusere på faktorer som evner og færdigheder. Dette kritikpunkt fremsættes også hos bl.a. Convery/ Coyle (1999), hvis argumentation for undervisningsdifferentiering omfatter både mentale faktorer (fx intelligens, sprogevne, kognitiv stil), affektive faktorer (fx motivation, holdning til fremmedsproget, intro- og ekstraversion) samt sociale faktorer (fx køn, alder, social og kulturel baggrund, samarbejdsevne). Den samlede benævnelse for disse faktorer er individuelle forskelle - et essentielt genstandsområde inden for sproglig læring, som jeg imidlertid ikke berører nærmere i denne artikel ${ }^{5}$.

En angrebsvinkel på undervisningsdifferentiering, som jeg i litteraturen på området savner opmærksomhed omkring, er den procesorienterede med udgangspunkt i grundlæggende aspekter af sprogindlærerens intersproglige udvikling. Denne forsømmelse vil jeg derfor råde bod på i denne artikel, foruden at jeg vil illustrere en IT-baseret sproglig læringsmodel, der muliggør effektuering af en procesorienteret differentieringsform set $\mathrm{i}$ et psykolingvistisk perspektiv.

\section{SLA og intersprog}

For nu ca. 30 år siden markeredes med SLA-forskningens ${ }^{6}$ opdukken et omsving fra et behavioristisk til et mentalistisk sprogligt læringssyn. Det stod klart, at læringsprocessen ikke var baseret på vanedannelse, men på regeldannelse, og man tillagde sprogindlæreren selv den aktive hovedrolle i denne kognitive proces baseret på hypotesedannelse og -afprøvning 7 .

\footnotetext{
4 I dansksproget litteratur på området bruges termerne learner, lørner, indlcerer og sprogindlcerer i flæng om den person, der tager del i en intersproglig læringsproces.

5 For uddybning, se fx Skehan (1989).

6 SLA: Second Language Acquisition.

7 Intersprogets gradvise udvikling i retning af målsproget kan beskrives som en proces bestående af hypotesedannelse og hypoteseafprøvning. Det er essentielt for sproglig læring, at indlærere fortsat udvikler deres hypoteser, og dermed deres intersprog, i retning af målsproget. For at en hypotese kan optages i intersproget skal den afprøves og evalueres
} 
I 1972 introducerede Selinker termen intersprog om det sprog, der hverken er modersmålet eller fremmedsproget, og som sprogindlæreren gradvist udvikler i retning af fremmedsproget. En grundlæggende del af forskningen inden for SLA beskæftiger sig med de psykolingvistiske faktorer, der betinger intersprogets gradvise udvikling i retning af målsproget. Man ser på, hvilken rolle input og output spiller, konvertering af input til intake, forarbejdningskapacitet, bevidstgørelse, opmærksomhed, mv.

I det følgende anskues udviklingen af sprogindlærerens intersprog som fremmedsprogsundervisningens overordnede sigte, og delaspekter af denne proces belyses ud fra udvalgte SLA-forskningsområder, der er specielt relevante i differentieringssammenhæng.

\subsection{Intersprogets grundlæggende karakteristika}

Selv om intersproget er en formalt og funktionelt reduceret version af fremmedsproget, betragtes det som fuldgyldigt i sig selv. De tre grundlæggende træk ved dette sprog er dets systematik, dynamik og variabilitet.

At intersproget er systematisk betyder, at det er regelbaseret, om end intersprogets regelsystemer i større eller mindre grad afviger fra målsprogets.

Det dynamiske aspekt ved intersproget manifesteres ved, at det er i konstant forandring, videreudvikles og revideres på basis af allerede internaliserede regler, hvis der vel at mærke arbejdes med det. I modsat fald kan det reduceres til et tidligere udviklingsstadium.

Intersprogets variabilitet giver sig udslag $\mathrm{i}$, at sprogindlæreren anvender flere konkurrerende former ved siden af den rigtige. Det vil sige, at der på samme tid kan forekomme sproglige eksempler på både en nyligt revideret intersprogsregel og en ældre fejlagtig version af samme. Dette forklares ved, at den intersproglige udvikling sker gradvist og ikke lineært.

ud fra efterfølgende feedback. Hvis hypotesen er korrekt, optages den i intersproget. Hvis hypotesen er ukorrekt, skal der dannes en ny hypotese. Herefter vil der ske en gradvis ændring af den forkerte hypotese til den korrekte hypotese. (Færch/Haastrup/ Phillipson 1984). 


\subsubsection{Forarbejdningskapacitet og opmarksomhed}

Inden for kognitionspsykologien, hvorfra forskningen i SLA henter en del af sit teoretiske grundlag, betragtes sproglig læring som informationsforarbejdning. Hermed menes en proces, igennem hvilken information lagres og organiseres i hukommelsen samt genkaldes, når man har brug for $\operatorname{det}^{8}$. Forskningen inden for dette område søger bl.a. at belyse de krav, informationsforarbejdningen stiller til kognitive ressourcer som forarbejdningskapacitet og opmærksomhed.

Det er en grundlæggende anskuelse inden for den kognitive psykologi, at mennesket, og dermed også sprogindlærere, har en begrænset kognitiv forarbejdningskapacitet. Denne begrænsning beskrives ud fra to dimensioner.

Den ene dimension har at gøre med evnen til informationsforarbejdning, dvs. den måde hvorpå sprogindlæreren håndterer information på basis af inputtets karakter og eksisterende viden. Hvis en sprogindlærer fx udsættes for en hastig talestrøm på fremmedsproget, kan der ske det, at evnen til at håndtere informationerne bliver overbelastet, $\mathrm{og}$ at den pågældende derfor kobler fra (McLaughlin/Rossman/McLeod 1983).

Den anden dimension har at gøre med den grad af opmærksomhed, en indlærer kan yde på et givet tidspunkt. Denne selektivitet udspringer af de krav, der stilles til løsning af en given opgave. I forbindelse med denne dimension skelner Shiffrin/Schneider (1977) imellem kontrollerede og automatiske processer. Som regel vil det forholde sig sådan, at ny og ikke tilegnet information fordrer kontrolleret forarbejdning under sprogindlærerens aktive og fokuserede opmærksomhed. Denne proces er ret langsom, sekventiel og belastende for forarbejdningskapaciteten i korttidshukommelsen. Derfor influerer en kontrolleret proces på sprogindlærerens evne til samtidigt at udføre flere opgaver, der kræver aktiv opmærksomhed og dermed forarbejdningsenergi. Omvendt foregår

8 Der skelnes imellem to lagre, dels arbejdslagret eller korttidshukommelsen, hvor information kan opbevares og forarbejdes i en ganske kort periode, dels langtidshukommelsen, det permanente informationslager. Hvad angår langtidshukommelsen er kapaciteten nærmest ubegrænset. Derimod er korttidshukommelsen yderst begrænset, hvilket betyder, at der er grænser for, hvor mange informationer man er i stand til at forarbejde ad gangen. 
anvendelse af en allerede tilegnet viden som en automatisk og mindre ressourcekrævende proces, der uden sprogindlærerens aktive opmærksom kan udføres hurtigere og med mindre besvær end den kontrollerede proces.

Disse faktorers indflydelse på fremmedsproglig læring belyses hos McLaughlin/Rossman/McLeod (1983: 145):

\begin{abstract}
"In the case of a beginning second language learner a considerable amount of cognitive effort may be needed simply to realize a correct, or at least an adequate, phonetic expression of individual words. At the same time, the learner needs to employ appropriate syntactic rules and must draw on a limited lexical system. Thus each component requires more or less work depending on how well-learned it is. The more welllearned a component skill is, the less effort (and processing time) required for its execution. The execution of new skills is costly in terms of workload involved and will occur only when other tasks and cognitive demands are minimized".
\end{abstract}

Hvilken grad af kognitiv forarbejdning en sproglig aktivitet udløser hos en sprogindlærer, er individuelt betinget $\mathrm{g}$ varierer fra sprogindlærer til sprogindlærer. Derfor giver det ikke mening at tilbyde alle studerende på et hold det samme forløb med de samme aktiviteter på det samme tidspunkt, da det vil fordre forskellige grader af kognitiv forarbejdning hos den enkelte i henhold til anvendelsesgraden af hhv. kontrollerede og automatiske processer samt til det stadium i den intersproglige udviklingsproces, hvorpå man befinder sig. Hvad der for nogle studerende vil være kognitivt uproblematisk, vil for andre indebære en kognitiv belastning og som følge heraf enten en hel eller delvis hindring for udførelsen af aktiviteten.

\title{
2.1.2. Intersprogets omstrukturering
}

Nunan (1999: 108-109) beretter om sine oplevelser fra sin første tid som underviser:

„The first thing I noticed was the alarming gap between what I was trying to teach my learners and the things that they actually appeared to be learning. I also fouind that the effect of my pedagogical effort sometimes seemed to make my learners worse, not better. (-) In time, I came to see (or rather my learners forced me to see), that my teaching was predicated on the assumption that learning another language was a process of erecting a linguistic „,building“ in a step-by-step fashion, one linguistic „brick“ at a time“. 
Den lineære og kumulative indfaldsvinkel til sproglig læring, som Nunan beskriver, er baseret på den præmis, at sprogindlærere lærer én sproglig struktur ad gangen, og at de skal beherske denne, før man går videre til den næste. Men sådan foregår læringsprocessen ikke.

Som nævnt, er intersproget variabelt og tilegnes gradvist. Analyser af taledata indsamlet med jævnlige intervaller over flere måneder viser, at sprogindlærere gennemløber fælles udviklingsstadier i deres tilegnelse af visse grammatiske strukturer (fx Johnston 1985; Pavesi 1986; Meisel/ Clahsen/Pienemann 1990). Eftersom de mellemliggende stadier i udviklingen hverken ligner modersmål eller målsprog, giver det anledning til at konkludere, at sprogindlærere ikke blot rekonstruerer deres modersmål i henhold til målsprogets normer, men at de snarere kreativt konstruerer målsproget gennem en proces, der gradvist bliver mere kompleks (Larsen-Freeman 1991).

Særdeles vigtig i denne forbindelse er den observation, at læringsprocessen hverken er lineær eller kumulativ, hvilket skyldes den omstrukturering, der karakteriserer udviklingen af intersproget:

\footnotetext{
"[Restructuring] occurs because language is a complex hierarchical system whose components interact in non-linear ways. Seen in these terms, an increase in error rate in one area may reflect an increase in complexity or accuracy in another, followed by overgeneralization of a newly acquired structure, or simply by a sort of overload of complexity which forces restructuring, or at least a simplification, in another part of the system" (Lightbown 1985: 177).
}

Det vil sige, at på trods af, at en indlærer synes at beherske en given struktur, er det ikke sjældent, at der forekommer midlertidige sproglige tilbagefald, når nye strukturer introduceres, fordi disse forårsager en omstrukturering af systemet.

Den gradvise, ikke lineære proces indikerer, at der er grund til i tilrettelæggelsen af undervisningen at indtænke cykliske forløb, hvor sproglige elementer med fordel gentages i forskellige kontekster. Dette indebærer, at man jævnligt vender tilbage til tidligere berørte sproglige fænomener og på samme tid inddrager nye synsvinkler, hvorved der sker en gradvis tilpasning og omstrukturering af den allerede eksisterende viden. Dog skal man her huske på, at der, så vidt muligt, skal tages højde for den individuelle indlærers intersproglige udviklingstrin for at en cyklisk model kan forventes at have en positiv læringsmæssig effekt. 


\subsubsection{Undervisning, læring og differentiering}

Sammenfattende kan man sige, at den diskrepans, sprogundervisere ofte oplever imellem, hvad de underviser i, og hvad de studerende konkret lærer, på sin side kan tillægges den diskrepans, den traditionelle holdundervisning kan fremprovokere imellem krav til kognitive ressourcer og den reelle kognitive forarbejdningsevne hos den enkelte studerende.

Dertil kommer, at det ikke giver mening at tilrettelægge en undervisning baseret på en fast plan karakteriseret ved et linearitets- og akkumuleringsprincip, når en sådan plan ikke harmonerer med den intersproglige udvikling, der er nonlineær og nonkumulativ.

Disse omstændigheder er vægtige argumenter for anvendelse af differentiering i fremmedsprogsundervisningen. Og det er netop her, computerens eksistensberettigelse for alvor kan manifestere sig, hvis man kan finde en model for sproglig læring, der optimalt tager selve læringsprocessens betingelser i betragtning.

\section{En model for sproglig læring}

Hos Ellis (1997:35) opstilles en model for sproglig læring baseret på intersprogskonceptet:

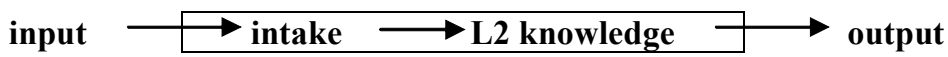

„The learner is exposed to input $^{9}$, which is processed in two stages. First, parts of it are attended to and taken into short-term memory. These are referred to as intake ${ }^{10}$. Second, some of the intake is stored in long-term memory as L2 knowledge. The processes responsible for creating intake and L2 knowledge occur within the 'black box' of the learner's mind where the learners interlanguage is constructed. Finally, L2 knowledge is used by the learner to produce spoken and written output ${ }^{11}(-)^{\text {“c. }}$

\footnotetext{
9 Input: de fremmedsproglige data, en sprogindlærer udsættes for gennem kontakt med fremmedsproget. Input kan også komme fra bevidstgørelse om sproglige regler.

10 Intake: hvad en sprogindlærer forstår af input, men ikke nødvendigvis er i stand til at anvende i praksis.

11 Output: det intersprog, en sprogindlærer producerer i skrift og tale
} 
22

Denne model vil jeg anvende som udgangspunkt for opstilling af en input- og outputorienteret indfaldsvinkel til sproglig læring. Den kan rumme aktiviteter, der kan hjælpe sprogindlæreren til at effektivisere såvel selve inputforarbejdningen ${ }^{12}$ som den hypoteseafprøvning, der manifesteres i det sproglige output. Formålet med at anskueliggøre denne tilgang skal forstås på baggrund af,

- at dens grundlæggende principper tager højde for processerne bag sprogindlærerens intersproglige udvikling

- at den optimalt muliggør differentiering på et psykolingvistisk grundlag, samt

- at den, af disse to årsager, med meget stor fordel kan udgøre fundamentet for en computerstøttet oparbejdelse af intersproget.

\subsection{En inputorienteret indfaldsvinkel til sproglig læring}

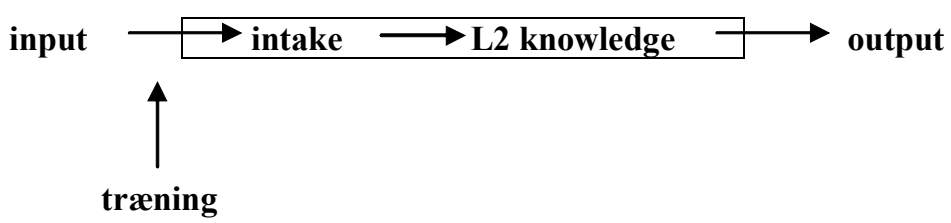

På basis af teorien om informationsforarbejdning, begyndte SLA-forskningen midt i 1970'erne at fokusere på inputtets rolle i den sproglige læringsproces. De heraf opståede forståelsesorienterede indfaldsvinkler til sprogundervisningen har til formål direkte at påvirke udviklingen af intersproget ved at manipulere de input, indlærerne udsættes for. Inputforarbejdning, der implicerer konvertering af input til intake, er en første forudsætning for, at der overhovedet finder læring sted. Af denne årsag tillægges inputforarbejdningen en stor rolle inden for denne forskningsgren.

Der findes forskellige inputorienterede tilgange ${ }^{13}$. Den, jeg vælger at tage udgangspunkt $i$, er formuleret af Ellis (1993), og mit valg er begrundet $i$, at hans model tildeler bevidstgørelse via eksplicit undervis-

12 Inputforarbejdning: konvertering af input til intake.

13 For en nærmere redegørelse, se Ellis (1999). 
ning i sproglige regler en faciliterende rolle i læringsprocessen, hvilket ikke mindst er essentielt for sprogundervisningen på en højere læreanstalt.

I relation til bevidstgørelsesfasens eksplicitering af sproglige regler foregår en forståelsesorienteret træning, der, som benævnelsen indikerer, har til formål at fremme indlærernes forståelse af et givet sprogligt fænomen. Ved at søge en optimering af inputforarbejdningen og dermed fremme af intake, ændres undervisningens fokus i første omgang fra produktion til forståelse. Med andre ord: indlærerne skal først have forstået et sprogligt fænomen, før de sættes til at producere det samme.

En forståelsesorienteret øvelsestypologi kan typisk rumme flg. grundlæggende handlinger ${ }^{14}$ :

- besvare spørgsmål

- identificere fænomener

- vurdere korrekthed

- foretage valg blandt flere mulige

- etablere sammenhænge imellem form-betydning/funktion

- udlede regler

- beskrive fænomener

- forklare fænomener kontrastivt

- diskutere og løse problemstillinger

Modellens forankring i psykolingvistiske undersøgelser gør, at den, i modsætning til den produktorienterede indfaldsvinkel, tager den menneskelige hjernes begrænsede forarbejdnings- og tilegnelseskapacitet $\mathrm{i}$ betragtning og fokuserer på aktiviteter, der kan hjælpe indlærere til at effektivisere inputforarbejdningen. Den mere traditionelle indfaldsvinkels fokus på output umiddelbart efter bevidstgørelsesfasen kan være ensbetydende med at stille større krav til indlærerne, end de kan klare, hvis de på produktionstidspunktet ikke har opnået tilstrækkelig forståelse af et sprogligt fænomen.

\footnotetext{
14 Praktiske eksempler på forståelsesorienterede øvelser til grammatikundervisningen kan ses i Ambjørn/Andersen (1999). Eksempler på samme øvetype til samtalefærdighed kan ses i Ambjørn (2000; 2001b).
} 


\subsection{En outputorienteret indfaldsvinkel til sproglig læring}

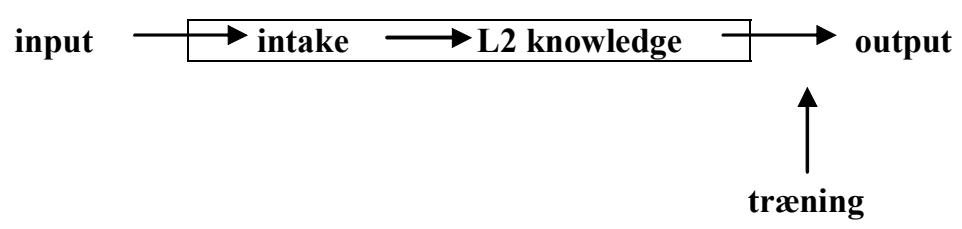

Inden for forskningen i inputforarbejdning er der forskellige opfattelser af den rolle, output spiller i den sproglige læringsproces. Årsagen til, at nogle forskere stiller sig lidt tvivlende over for outputtes rolle, er læringsretningen, som illustreret ovenfor: det kan forekomme ulogisk først at starte træningsfasen i den sidste del af processen i stedet for at sætte ind over for den måde, hvorpå en indlærer forarbejder input med henblik på at fremme intake og derved påvirke den eksisterende L2 viden. Dertil kommer, at output ikke som sådan er et led i selve processen, men snarere kan karakteriseres som en manifestation af samme (Gass 1997). Output eller produktion betragtes således af nogle forskere som en måde at praktisere en allerede eksisterende viden på og ikke som en vej til skabelse af viden.

Men vægtige argumenter for, at output faktisk kan spille en aktiv rolle i læringsprocessen, fremføres hos Swain (1985), hvor termen comprehensible output eller pushed output introduceres. Hermed menes „being pushed toward the delivery of a message that is not only conveyed, but that is conveyed precisely, coherently, and appropriately" (ibid: 249).

Swain anviser forskellige måder, hvorpå indlærere kan lære af deres eget output:

- output tjener til hypoteseafprøvning, der på sin side udløser en positiv eller negativ feedback, så indlæreren kan få be- eller afkræftet deres hypoteser (jf. fodnote 7)

- output kan have en bevidstgørende funktion, hvorved indlærerne hjælpes til at bemærke sproglige mangler i deres intersprog. Dermed menes, at de i tale- eller skriveprocessen opdager, at de savner viden om visse sproglige elementer, som er af betydning for det, de vil udtrykke

- output er en medvirkende faktor for udvikling af automatiseret sprog og dermed for flydende sprogbrug 
- output har en potentiel signifikant rolle i udviklingen af den morfologiske og syntaktiske kompetence og dermed for korrekt sprogbrug ${ }^{15}$.

Som et første led i den produktive træning giver det mening at anvende bundne øvetyper, der specifikt fokuserer på afgrænsede sproglige fænomener. Med denne afgrænsning tages der højde for, at indlæreren har en begrænset forarbejdningskapacitet, idet denne øvetype ikke belaster korttidshukommelsen så meget som mere frie øvetyper.

Fx til grammatikundervisningen kan der her være tale om de velkendte øvelser af typen 'indsætning', 'fejlretning', 'eksempelfabrikation', 'sproghandlingsrealisation (form-funktion)', oversættelser på sætningsplan (se fx Jensen 1999) 16 .

Det skal frarådes i denne fase at anvende mekaniske drills, som hviler på et behavioristisk læringssyn og desværre fortsat er ret anvendte i computerbaseret materiale. DeKeyser (1998: 53):

\begin{abstract}
„(-) mechanical drills provide practice in a very peculiar behavior, a „language-like-behavior", which consists of linking forms with other forms, of shuffling forms around, according to a pattern held in working memory, without ever linking those forms with meaning, that is, without the student ever engaging in the target behavior of using language. As a result, no link between forms and meaning is established in long-term memory (-)“.
\end{abstract}

Frie(re) produktive øvelser lægger op til mere selvstændig og kreativ sprogproduktion. Her integreres de forudgående delelementer i mere komplekse kontekster, der tillader indlærerne at mobilisere al deres fremmedsproglige viden og kunnen. Men dette betyder så også, at kravet til de kognitive ressourcer kan øges, og at betydningen af at være i besiddelse af så meget automatiseret sprog som muligt tydeligt træder frem her. Der kan være tale om fx oversættelse af hele tekster, frie skriftlige fremstillinger og frie samtaleøvelser ${ }^{17}$.

15 For uddybning af disse punkter, se Swain $(1985 ; 1995)$.

16 Til undervisning i samtalefærdighed kan ses en række bundne produktive øvelsesforslag i Ambjørn (2001b).

17 Til undervisning i samtalefærdighed kan ses en række frie produktive øvelsesforslag i Ambjørn (2001b). 


\subsection{En input- og outputorienteret model til sproglig læring}

Inden for SLA-forskningen diskuteres det, hvorvidt den inputorienterede indfaldsvinkel til sproglig læring kan have en faciliterende effekt på såvel forståelse som på produktion. Ellis (1999), der nærmere har studeret forskningsresultaterne på området, konkluderer:

\footnotetext{
„While it is possible to conclude that processing instruction promotes intake, it is not yet possible to claim that it promotes acquisition (i.e. interlanguage development). There is no clear evidence that learners can use the target structure in communicative language use" (ibid: 74).
}

Af samme årsag anfører Ellis (1993; 1999), at den inputorienterede undervisningsform bør supplere en produktiv, kommunikativt orienteret undervisning - ikke erstatte den. Hertil vil jeg føje, at også andre former for undervisning med fordel kan udgøre et supplement. Der skal selvsagt være overensstemmelse imellem formål med givne forløb og undervisning, og ikke alle forløb har et mundtligt kommunikativt sigte.

At output spiller en væsentlig rolle, mener jeg ikke, at der kan herske nogen tvivl om. Men den traditionelle ensidige output-fokusering er en medvirkende faktor til skabelse af de indlæringsmæssige problemer, sprogundervisere kan opleve, at deres studerende har. Og den er en vægtig årsag til, at man ikke så sjældent må registrere, at der er uoverensstemmelse imellem, hvad der undervises i, og hvad der rent faktisk læres.

De nyere inputorienterede indfaldsvinkler til sproglig læring har til formål direkte at påvirke udviklingen af intersproget ved at manipulere de input, indlærerne udsættes for, hvilket på sin side formodes at have en faciliterende effekt på en sprogindlærers kapacitet til at producere output $i$ en automatiserende træningsfase. Jeg opfatter derfor den input- og den outputorienterede indfaldsvinkel som komplementære.

Den samlede model (Ellis 1997), som illustreret nedenfor, tager selve processen i den sproglige læring i betragtning, og det er heri dens force ligger. Modellen giver endvidere mulighed for optimal udvikling af et computerstøttet differentieret undervisningsforløb baseret på de psykolingvistiske faktorer, der yder indflydelse på udviklingen af intersproget. Et sådant forløb skitseres i næste afsnit. 


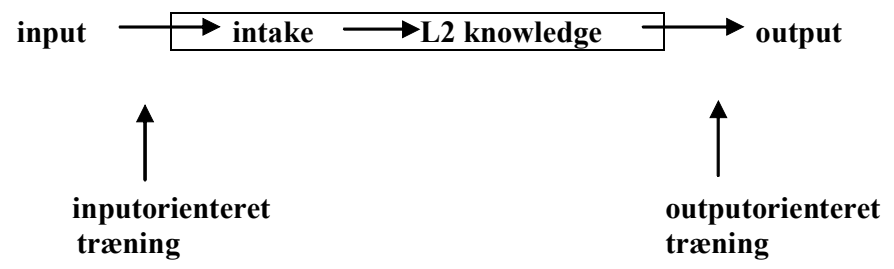

\subsection{Et computerstottet differentieret læringsforløb}

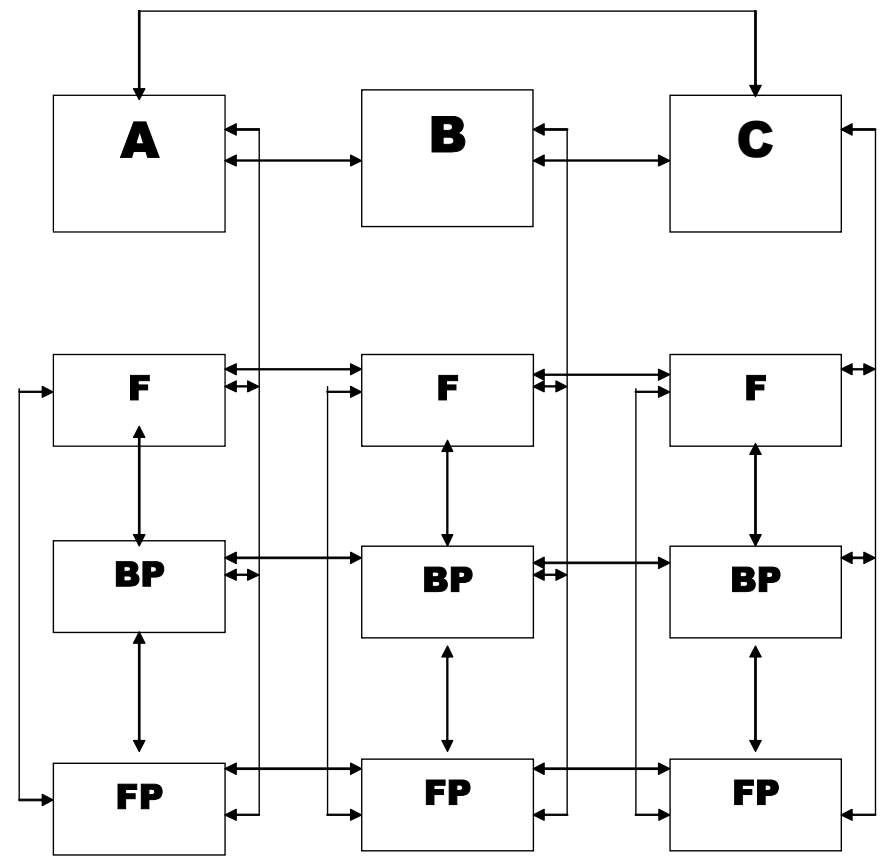

F: forståelsesorienterede øvelsestyper

BP: bundne produktive øvelsestyper

FP: frie(re) produktive øvelsestyper 
Det skal understreges, at den model for et computerstøttet sprogligt læringsforløb, der her skitseres, ikke skal opfattes som en egentlig metode, men som et sæt grundlæggende principper, der kan danne udgangspunktet for mulige forløbstilrettelæggelser ${ }^{18}$.

A, B og C skal bredt betragtes som fagrelevante informationsdatabaser af en i princippet enhver tænkelig karakter, der på forskellige niveauer (lavt, middel, højt) kan bibringe den studerende en viden, der herefter skal indarbejdes i intersproget. Arbejdet med sproglig bevidsthed udgør således en integreret del af forløbsmodellen.

Schmidt (1990) har fremsat den hypotese, at intake ikke kan finde sted, uden at indlærerne i input eksplicit bevidstgøres om sproglige fænomener. Denne teori nyder overvejende konsensus inden for den moderne sprogundervisning, og af samme årsag går den aktuelle diskussion ikke så meget på, om man skal bevidstgøre eller ej, men snarere på selve indfaldsvinklen til denne bevidstgørelse.

Via links kan den studerende efter behov springe fra en databases niveau til en anden databases niveau, fra databaserne til de forståelsesorienterede træningsformer og herfra videre til de produktive øvelser, ligeledes på forskellige niveauer. Træningssystemet kan således opfattes progressivt, idet man kan sige, at forståelse udgør en forudsætning for produktion, og at den bundne produktion på sin side kan have en faciliterende effekt på den frie(re) produktion. Men på samme tid tages der højde for, at intersprogsudviklingen hverken er lineær eller kumulativ, idet den studerende kan navigere rundt $\mathrm{i}$ forløbet i overensstemmelse med det individuelle intersprogs gradvise omstrukturering og udvikling.

Med forskellige indbyrdes forbundne færdighedsniveauer såvel i forløbets bevidstgørelsesfase som i træningsfasen, samt med en såvel input- som outputorienteret træning, der kan afvikles cyklisk (jf. afsnit 2.1.2) sikres den optimale procesorienterede undervisningsdifferentiering baseret på psykolingvistisk forskning. Hermed tages der højde for det faktum, at ikke alle studerende på samme undervisningstrin lærer med samme hastighed, besidder den samme kognitive forarbejdningskapacitet

\footnotetext{
18 Modellen er i Ambjørn (2001a) anvendt til at illustrere oparbejdelsen af den grammatikalske kompetence, men kan i princippet anvendes til oparbejdelse af mange andre sproglige kompetenceområder.
} 
eller befinder sig på samme stadium i deres intersproglige udvikling, og at deres individuelle behov af samme årsag er forskellige.

Som en del af hypoteseafprøvningen spiller feedback en vigtig rolle i den intersproglige læringsproces (jf. fodnote 7). Derfor skal der som et led $\mathrm{i}$ træningen indbygges forskellige former for differentierede feedback- og kontaktfunktioner (Ambjørn 2001a):

- en automatisk feedbackfunktion, der i tilfælde af fejlsvar giver den rigtige løsning

- en automatisk feedbackfunktion, der i tilfælde af fejlsvar gør opmærksom på dette, men i stedet for at bringe den rigtige løsning, henviser til en relevant kilde i en eller flere af de til forløbet knyttede informationsdatabaser

- en automatisk feedbackfunktion, der i tilfælde af fejlsvar gør opmærksom på dette, men i stedet for at bringe den rigtige løsning eller henvise til en relevant kilde i en given informationsdatabase, lader det være helt op til den enkelte studerende at rette fejlen

- mulighed for kontakt med underviser via et kommunikationssystem

- mulighed for at søge hjælp og diskutere sproglige problemstillinger i et dertil oprettet diskussionsforum i et kommunikationssystem.

Hvad angår forløbsmodellens tekniske omsættelighed til computermediet, falder dette spørgsmål uden for denne artikels egentlige genstandsområde. Som allerede nævnt er det imidlertid primært et spørgsmål om inden for eksisterende elektroniske materialer at søge, finde, udvælge, sammensætte, linke og selv supplere med udarbejdelse af nyt elektronisk materiale, da det må erkendes, at ,programmet der kan alt" ikke eksisterer og med meget lidt sandsynlighed kommer til det inden for en overskuelig fremtid.

I relation hertil skal det bemærkes, at selv om et givet computerbaseret materiale vurderes til ikke i sig selv at besidde et fuldgyldigt læringspotentiale, er det ikke ensbetydende med, at man kategorisk behøver at afvise hele materialet. Det viser sig ikke ganske sjældent, at man kan finde anvendelige delelementer, som evt. kan sammensættes med anvendelige delelementer fra andre materialer og programmer til et sammenhængende læringsforløb. 
Dertil kommer, at et forløb ikke altid i sin fulde helhed kan opbygges elektronisk, da teknologien på flere områder fortsat har sine begrænsninger. Et eksempel herpå er oparbejdelse af mundtligheden, der ganske vist med meget stor fordel kan trænes elektronisk, hvad angår den forståelsesorienterede og bundne produktive fase, men hvor teknologien kommer til kort i den frie mundtlige produktion. Om end vi har de (a)synkrone computermedierede interaktionsmuligheder, er problemet, at de genremæssigt udgør et hybridmedium mellem skrift- og talesprog, og man derfor må sætte spørgsmålstegn ved hensigtsmæssigheden i helt at lade dette medium overtage udviklingen af mundtligheden.

\section{Autonomi via medansvar for egen læring}

Autonomibegrebet er både historisk og teoretisk forbundet med den kommunikativt orienterede sprogundervisning, der vinder indpas fra starten af 1970'erne. Dette hænger naturligt sammen med, at behovet for selvstændighed højnes i forbindelse med løsning af de opgavetyper, som fordrer deltagercentreret interaktion.

Anskuet ud fra en bredere læringsorienteret synsvinkel er relationen imellem intersprogs- og autonomikonceptet imidlertid specielt evident. Udviklingen af et intersprog anskuet som en individuel sproglig læringsproces kan i sagens natur ikke finde sted uden indlærerens aktive deltagelse. Og denne proces fordrer på sin side større eller mindre grad af selvstændig adfærd.

Hos Nunan (2000:1) defineres autonomibegrebet som følger:

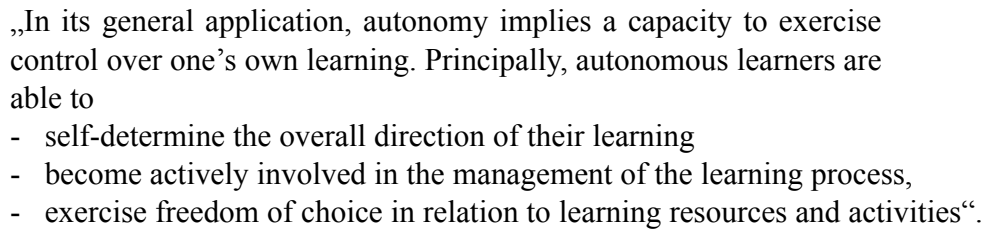

„In its general application, autonomy implies a capacity to exercise control over one's own learning. Principally, autonomous learners are able to

- self-determine the overall direction of their learning

- become actively involved in the management of the learning process,

- exercise freedom of choice in relation to learning resources and activities“.

Denne udlægning, der umiddelbart kan forekomme lidt virkelighedsfjern, ville fordre en nærmest medfødt indsigt i sproglig læring og evne til at træffe kvalificerede valg. Men hvis man accepterer, at der findes forskellige grader af autonomi, som nås igennem en proces, hvor man systematisk og fortløbende bevidstgør de studerende om sproglig læring, forekommer den mere realistisk. Mit bud er således, at autonomi, som 
defineret ovenfor, kun kan sættes som et helt overordnet og langsigtet mål. Som et delmål i retning af fuld autonomi, synes udvikling af medansvar og dermed af den medansvarlige sprogindloerer mere realisabelt.

En læring-om-læring-proces, der efterhånden sætter den studerende i stand til at deltage i planlægning, revision og evaluering af egen læring, kan naturligvis ikke foregå uden underviserens medvirken. Det vil sige, at der etableres et løbende samarbejde underviser og studerende imellem om, dels at udvikle den studerendes intersprog, dels at give den studerende den fornødne indsigt i diverse forhold omkring sproglig læring for dermed at bibringe den studerende et ægte medansvar for denne proces.

I processen fungerer underviseren som faglig vejleder og proceskonsulent. Kært barn har, som bekendt, mange navne, og menes barnet endvidere at være en nyskabelse, synes kreativiteten ingen ende at ville tage. Her følger et udsnit af benævnelser fra den engelsksprogede litteratur for underviserens ,nye“ ning: facilitator, mediator, coach, consultant, counsellor, guide, communicator, navigator, designer of tasks, choreograph, architect, resource person, doctor, diagnostician, midwife.

Imidlertid skal det understreges, at integrationen af teknologien i sprogundervisningen ikke har afstedkommet et skift i underviserens rolle, sådan som man kan læse i mangfoldige publikationer på området. En sprogunderviser kan i sagens natur ikke udføre nogen anden rolle end vejlederens og konsulentens mv., da det er forbeholdt sprogindlæreren at være den egentlige hovedaktør i egen intersproglig udvikling. Men måske man kan formulere det på den måde, at den computerstøttede undervisning kan skabe større mulighed for selvstændig læringsadfærd, og at dette på sin side er en medvirkende faktor for tydeliggørelse både af en allerede eksisterende underviserrolle samt af betydningen af at forvalte denne rolle optimalt.

En optimering af interaktiviteten i den studerendes og underviserens samarbejdsproces må nødvendigvis indebære, at den studerende bevidstgøres omkring grundlæggende og relevante undervisnings- og læringsmæssige aspekter samt lærer at gøre brug af midler og værktøjer til fremme af egen læringsproces: 


\section{2}

1. Fagets mål, indhold og form

Via officielle fagbeskrivelser har de studerende mulighed for at orientere sig om et fags mål, indhold og form. Ikke desto mindre er der grund til at tydeliggøre dette $\mathrm{i}$ form af mere uddybende beskrivelser, som underviseren kan lægge på sin hjemmeside. Dette er medvirkende til at gøre et givet fag på et givet tidspunkt mere vedkommende for den enkelte.

2. Generelle og færdighedsspecifikke aspekter af sproglig læring

Uden en vis indsigt $i$ generelle og færdighedsspecifikke aspekter af sproglig læring vil den studerende aldrig kunne tage et ægte medansvar for egen læring, herunder træffe kvalificerede valg, vurdere egen læringsproces, vurdere sig selv i rollen som indlærer eller deltage $i$ en egentlig interaktiv dialog med underviseren herom.

Et første udgangspunkt kunne meget vel være bevidstgørelse om oparbejdelse af den intersproglige kommunikative kompetence som det grundlæggende formål med al sprogundervisning.

Endvidere bør indgå bevidstgørelse om læringsstrategier:

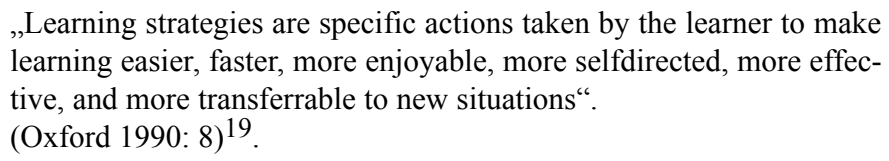

Eksempler på færdighedsspecifikke aspekter af sproglig læring kunne være bevidstgørelse om produkt- vs. procesorienteret skrivepædagogik, direkte vs. indirekte oparbejdelse af den leksikalske kompetence, intensiv vs. ekstensiv tekstlæsning osv.

\section{Metoder og indfaldsvinkler til at nå et givet mål}

Den studerende har til hver en tid krav på at vide både hvilken metode eller indfaldsvinkel til sproglig læring, der anvendes i en konkret situation, samt få en teoretisk begrundelse herfor. Jeg vil ikke i denne forbindelse undlade atter at harcelere over, at alt for meget computerbaseret materiale undlader at forholde sig eksplicit til en metode eller indfaldsvinkel, hvilket nødvendiggør, at underviseren påtager sig denne opgave på producentens vegne.

19 Jeg henviser til samme kilde for en meget udførlig indføring i metakognitive, kognitive, sociale og affektive læringsstrategier på et både teoretisk og praktisk plan. 
4. Læringsmæssige formål med givne aktiviteter

Betydningen heraf fremhæves på bedste vis hos Nunan (2000:12):

\begin{abstract}
„Making goals explicit to learners has a number of important pedagogical advantages. In the first place, it helps to focus the attention of the learner on the tasks to come. This enhances motivation. Research shows that a program in which goals are made explicit leads to higher student performance than programs in which goals are implicit. (-) Goal setting can have exceptional importance in stimulating L2 learning motivation, and it is therefore shocking that so little time and energy are spent in the L2 classroom on goal setting“".
\end{abstract}

Hvad angår forholdet imellem computerbaseret materiale og eksplicitering af det læringsmæssige formål med givne aktiviteter, gør det samme sig gældende som under pkt. 3.

\title{
5. Fremgangsmåde til løsning af opgaver
}

Når de studerende arbejder selvstændigt, er det essentielt for læringsprocessen, at de griber opgaverne an på en hensigtsmæssig måde. I modsat fald risikerer man, at de enten ikke lærer noget, eller, i værste fald, lærer noget forkert. Derfor bør de, som led i det selvstændige sprogarbejde, kunne støtte sig til redegørelser, hvoraf det fremgår, både hvad det læringsmæssige formål med en given opgave er (jf. pkt. 4), og hvordan opgaven bør gribes an. Hermed mener jeg ikke, at de studerende skal fratages medindflydelse på løsning af en opgave. Jeg henleder blot opmærksomheden på det tilrådelige $\mathrm{i}$, at de, i de indledende faser i læring-omlæring-processen, rådfører sig med underviseren, hvis de ændrer radikalt på fremgangsmåden til løsning af opgaver.

\section{Logbog som samarbejdsværktøj ${ }^{20}$}

Interaktiviteten $\mathrm{i}$ den studerendes og underviserens samarbejdsproces kan yderlige forstærkes gennem anvendelse af læringslogbogen defineret som et værktøj, underviseren og den studerende kan anvende til planlægning, gennemførelse og evaluering af et undervisningsforløb.

Logbogen kan indeholde forskellige journalafsnit, som løbende ajourføres af de studerende selv såvel i løbet af semestrene som i de skemafri

\footnotetext{
20 Se også fx Dam (1999).
} 
34

perioder. På denne måde gives de studerende løbende indsigt i og overblik over deres egen læringsproces, som derved også bliver mere selvstændig. Endvidere gør logbogen de studerende mere bevidste og reflekterende så de sættes i stand til at tage et ægte medansvar for egen læring.

Med jævne mellemrum foreviser de studerende underviseren deres logbog. Med udgangspunkt i de studerendes optegnelser, kommentarer og selvevalueringer kan underviseren lettere orientere sig om, hvordan den enkeltes læringsproces skrider frem og med udgangspunkt i logbogen give studiemæssige råd og vejledninger. Således kan logbogen med stor fordel danne grundlaget for individuelle konsultationer med underviseren.

\section{Afslutning}

Formålet med denne artikel har ikke været at skabe et nyt differentieringskoncept, men at bidrage til en videre diskussion af, hvordan man kan optimere den individuelle sprogindlærers læringsproces ved i et IT-baseret undervisningsforløb at indtænke et hensyn til de forskellige grader af færdighed, parathed og behov, der altid vil være til stede i et heterogent læringsrum.

Som nævnt, tillægger forskningen inden for SLA den individuelle sprogindlærer den aktive hovedrolle i den intersproglige udvikling. Om end denne forskning også anerkender de individuelle forskelles indvirkning på processen, fokuserer den især på psykolingvistiske faktorer, som, for mig at se, er substantielle for et mere validt og mere differentieret differentieringskoncept.

IT-integration øver pr. definition ikke positiv indflydelse på udbyttet af et sprogligt forløb og afstedkommer i lige så ringe grad undervisningsdifferentiering, med mindre dets opbygning indbefatter de kriterier, der karakteriserer den intersproglige udvikling. Hermed kan det konkluderes, at det påhviler underviserne at tilrettelægge sproglige læringsforløb, der er baseret på en kritisk selektering og sammensætning af en bred vifte af forskelligt elektronisk materiale på forskellige niveauer og med forskellige læringsmæssige delmål. Kun på denne vis er det muligt optimalt at tilgodese den undervisningsdifferentiering, som er computermediets raison d'être inden for sproglig læring. 


\section{Litteraturliste}

Ambjørn, Lone/Andersen, Vibeke 1999: Receptive øvelser til grammatikundervisningen $i$ spansk. Internt undervisningsmateriale R145, Spansk Institut, Handelshøjskolen 1 Århus.

Ambjørn, Lone 2000: Spansk sprogbrug. Kommunikative mønstre i talt diskurs. Internt undervisningsmateriale R151, Spansk Institut, Handelshøjskolen i Århus.

Ambjørn, Lone 2001a: Inputorienteret oparbejdelse af den grammatikalske kompetence. Web-publikation, HHÅ's Forskningsdatabase, http://www.hba.dk/fsk/pdfs/ 0003040.pdf

Ambjørn, Lone 2001b: Talt interaktion anskuet i et diskursivt, pragmatisk og strategisk perspektiv. Web-publikation, HHÅ’s Forskningsdatabase, http://www.hba.dk/fsk/pdfs/ 0003049.pdf

Anderson, John R. 1982: Acquisition of cognitive skill. Psychological Review, 89/4, 369-406.

Anderson, John R. 1995: Learning and memory: An integrated approach. New York: Wiley.

Cheng, P. W. 1985: Restructuring versus automaticity: Alternative accounts of skill acquisition. Psychological Review 92: 214-23.

Clark, Richard E. 1983: Reconsidering research on learning from media. Review of Educational Research, 53/4, 445-459.

Convery, Anne/Coyle, Do 1999: Differentiation and individual learners. - A guide for classroom Practice. Pathfinder 37, London: CILT.

Dam, Leni 1999: Logbøger og elevmapper i sprogundervisningen. Sprogforum, 15, 711.

Doughty, Catherine/Williams, Jessica 1998: Focus on form in classroom second language acquisition. Cambridge: Cambridge University Press.

DeKeyser, Robert 1998: Cognitive perspectives on learning and practicing second language grammar. I Doughty/Williams: Focus on form in classroom second language acquisition, 42-63.

Ellis, Rod 1993: The structural syllabus and second language acquisition. TESOL Quarterly, 27/1, 91-113.

Ellis, Rod 1997: Second language acquisition. Oxford: Oxford University Press.

Ellis, Rod 1999: Input-based approaches to teaching grammar: A review of classroomoriented research. Annual Review of Applied Linguistics, 19, 64-80.

Færch, Claus/Haastrup, Kirsten/Phillipson, Robert 1984: Learner language and language learning. København: Gyldendals Sprogbibliotek.

Garret, N. 1991: Technology in the service of language learning: Trends and issues. Modern Language Journal, 75/1, 74-101. 


\section{6}

Gass, Susan M. 1997: Input, interaction, and the second language learner. Mahwah (New Jersey): Lawrence Erlbaum Associates, Publishers.

Jensen, Kjær 1999: Produktive øvelser til grammatikundervisningen i spansk. Internt undervisningsmateriale R146, Spansk Institut, Handelshøjskolen i Århus.

Johnston, M. 1985: Syntactic and morphological progressions in learner English. [Research report]. Department of Immigration and Ethnic Affairs, Australia.

Larsen-Freeman, Diane 1991: Second language acquisition research: Staking out the territory. TESOL Quarterly, 25/2, 315-350.

Lightbown, Patsy M. 1985: Great expectations: Second language acquisition research and classroom teaching. Applied Linguistics 6.

McLaughlin, Barry 1990: Reestructuring. Applied Linguistics, 11/2, 113-128.

McLaughlin, Barry/Rossman, Tammi/McLeod, Beverly 1983: Second language learning: An information-processing perspective. Language Learning, 33/2.

Meisel, J./Clahsen, H/Pienemann, M.: On determining developmental stages in natural second language acquisition. Studies in Second Language Acquisition, 3/1, 109-135.

Nunan, David 1999: Second language teaching and learning. Boston (Massachusetts): Heinle \& Heinle Publishers.

Nunan, David 2000: Autonomy in language learning. Plenary presentation, ASOCOPI 2000, Cartegena, Colombia, oktober 2000. Homepage, presentations.

Oxford, Rebecca 1990: Language learning strategies. Boston (Massachusetts): Heinle \& Heinle Publishers.

Pavesi, M. 1986: Markedness, discoursal modes, and relative clause formation in a formal and an informal context. Studies in Second Language Acquisition, 8/1, 38-55.

Schmidt, Richard W. 1990: The role of consciousness in second language learning. Applied Linguistics, 11/2, 129-158.

Schneider, W./Shiffrin, R. 1977: Controlled and automatic human information processing, II: Perceptual learning, automatic attending and a general theory. Psychological Review, 84, 127-190.

Selinker, Larry 1972: Interlanguage. International Review of Applied Linguistics 10, 209-230.

Skehan, Peter 1989: Individual differences in second-language learning. London: Edward Arnold.

Swain, Merrill 1985: Communicative competence: Some roles of comprehensible input and comprehensible output in its development. I S. Gass/C. Madden (eds): Input in second language acquisition. Rowley, MA: Newbury House, 235-253.

Swain, Merrill 1995: Three functions of output in second language learning. I Cook/ Seidlhofer (eds): Principle and practice in applied linguistics. Oxford University Press, 125-144. 
Tomlinson, Carol Ann 2000: How to differentiate instruction. Reconcilable differences? Educational Leadership, 58/1, 1-7. http://www.ascd.org/readingroom/edlead/0009/ tomlinson.html

Warschauer, Mark 1996: Computer-assisted language learning: An introduction. I S. Fotos (ed): Multimedia language teaching. Tokyo: Logos International, 3-20. Reprinted version: http://www.gse.uci.edu/markw/call.html 


\section{When Talk is a Science...}

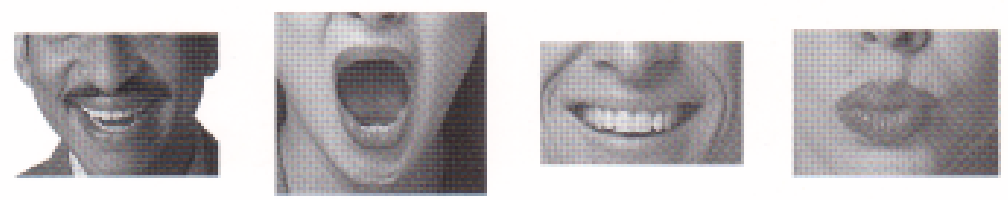

\section{Linguistics and Language Behavior Abstracts}

Comprehensive, cost-effective, timely coverage of current ideas in linguistics and language research

Abstracts of articles, books, and conference papers from nearly 1,500 journals published in 35 countries; citations of relevant dissertations as well as books and other media.

Available in print or electronically through the Internet Database Service from Cambridge Scientific Abstracts (www.csa.com).

Contact sales@csa.com for trial Internet access or a sample issue.

\section{Linguistics \& Language Behavior Abstracts}

Published by CSA 